\title{
Economics of rice production under rice zone in Gorkha District, Nepal
}

\author{
Sandip Paudel, Sovit Parajuli, Bishal Mahatara, Srijan Budhathoki, and Rishi Ram Kattel \\ Agriculture and Forestry University, Rampur, Chitwan, Nepal \\ Corresponding author e-mail: mrsandippaudel@gmail.com \\ (Received: 19/12/2020; Revised: 20/05/2021; Accepted: 18/06/2021)
}

\begin{abstract}
A research was conducted at the Gorkha district to access the economics of rice production. The Stratified Random Sampling technique was used in the research. Both primary and secondary data were used in this study. Altogether 120 respondents were surveyed. Data were analyzed using software like SPSS and MS-excel. The average rice cultivation area (spring and summer) was 0.47 hectare. Based on the average rice cultivation area, farmers were categorized into a smallholding (67 in number) and medium and large holding farmers (53 in number). The majority of the respondents were janajati and the majority of the household head had a primary level of education. The major cost of rice production was incurred in labor cost i.e., $75 \%$ compared to other inputs. The return from the rice was obtained from rice grains and straw with an overall contribution of $79.5 \%$ and $20.5 \%$ respectively. The $\mathrm{BC}$ ratio on average was found 1.28 while the $\mathrm{BC}$ ratio of the medium and large farmers was found higher than the small farmers, indicating rice production was profitable in the study area. Insect pests and diseases were found to be the most serious production problem among the several problems, with index value $(I=0.867)$. In short, rice cultivation is the primary priority among the farmers as it helps in food security. Hence it is recommended that the timely application of agricultural inputs, optimum utilization of input resources helps to foster rice production in those areas, consequently
\end{abstract} making it a more profitable occupation.

Keywords: $\mathrm{BC}$ ratio, Inputs, Problems.

\section{INTRODUCTION}

Rice has fed a greater number of people from the very long period of time than any other crop since it was domesticated between 8,000 to 10,000 years ago (Greenland, 1997). It is the most important food crop of the developing world and the staple food of more than half of the world's population. The cultivation of rice is said to have immense significance to food security of Asia, where more than $90 \%$ of global rice is produced and consumed (FAO, 2010). By the year 2025, it is estimated that, the world's farmers should produce about $60 \%$ more rice than at present to meet the food demands of the expected growing world population at that time (Fageria, 2007). It feeds 100 million Asian households that plant a total of 60 million ha land with rice (Pandey, Gauchan, Malabayabas, \& Hardy, 2012). It accounts for more than 40 percent of caloric intake in tropical Asia, reaching more than 65 percent in many countries and for many poor people (Fairhurst \& Dobermann, 2002).

Agriculture is the backbone of Nepalese economy contributing about $27.10 \%$ in national GDP (MOALD, 2017). Rice is the dominant crop of South Asia including Nepal, playing a significant role in economic and agricultural development, also in reducing poverty (Gumma, Gauchan, Nelson, Pandey, \& Rala, 2011). More than 1,700 rice landraces are reported in Nepal growing from altitude of 60 to 3, $050 \mathrm{~m}$ (Mallick, 1981). Rice ranks the first among cereal crops in terms of area, production and livelihood of the people. As the most important staple food of Nepalese people, rice supplies about $40 \%$ of the food calorie intake and contributes nearly $20 \%$ to the agricultural gross domestic product (AGDP) (MoAD, 2015). Most of the rice is produced in Terai region of Nepal.

On an average, Nepalese consume about $120 \mathrm{~kg}$ milled (or $200 \mathrm{~kg}$ paddy) rice per year and one-third of the total calorie intake in Nepal is supplied through rice. Rice alone contributes about 53\% to the total cereal food production (Tripathi, Bhandari, \& Ladha, 2018). In the year 2017/18 the import of cereals from different countries is in NRs. 45 billion, while the export is only in NRs. 16 Million (Depatment of Customs, 2017/18). The rice import has increased by $21 \%$ and has reached more than NRs. 24.5 billion (Kafle, 2019).

Gorkha is one of the Hilly districts of Nepal according to the administration but it is also considered as Himalayan region from the geographical point of view. It lies between $27^{\circ} 15^{\prime \prime}$ to $28^{\circ} 15^{\prime \prime} \mathrm{N}$ latitude and $83^{\circ} 27^{\prime \prime}$ to $84^{\circ} 58^{\prime \prime}$ E longitudes. The total area of this district is $3610 \mathrm{~km}^{2}$. The district has the altitude of $228 \mathrm{~m}-8136$ $\mathrm{m}$ above sea level. It is characterized by the maximum annual average temperature of $32^{\circ} \mathrm{C}$ and minimum 
annual average temperature of $6.6^{\circ} \mathrm{C}$ with a maximum annual rainfall of $554.4 \mathrm{~mm}$.

Gorkha is one of the potential areas for rice production. Different varieties of rice like, Sabitri, Ramdhan, Basmati, Anadi, Gorakhnath, US 312 etc., are grown in these areas. In these areas, rice is grown in two seasonsboth spring and summer. It is also a suitable site for the seed production as well.

\section{Trend of rice yield in Nepal and Gorkha district}

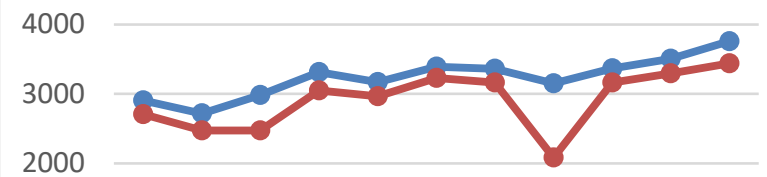

1000

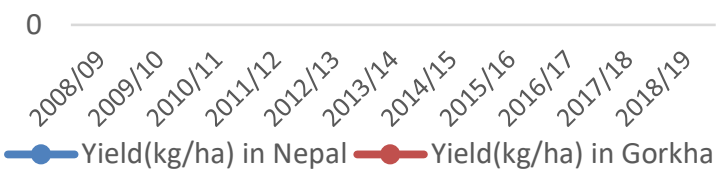

Figure 1. Trend of rice yield in Nepal and Gorkha district

\section{MATERIALS AND METHODS}

The survey research was carried out in Gorkha district. Gorkha is one of the Hilly districts of Nepal according to the administration but it is also considered as Himalayan region from the geographical point of view, located in Gandaki province, northern side of Prithivi highway. It is geographically linked to China in the North, Lamjung and Manang in the West, Dhading in the west and Chitwan and Tanahun in the south. In the context of the federal system, it consists of 2 Municipality and 9 Rural Municipality.

\section{Sample and sampling techniques}

The study site Gorkha Municipality, Palungtar Municipality, Siranchowk RM and Sahid-lakhan RM were selected for the sampling because of high potential of production than other area. Altogether 120 household samples were taken using stratified random sampling procedure. Simple interview schedule was developed including the information on socioeconomic characteristics of the target group, existing production practices, agricultural land holdings, farm characteristics, income from rice production, and farmer access to extension services. The interview scheduled was pretested prior to administering to the actual respondents for checking the reliability and validity of interview schedule. The pre-testing was done on $10 \%$ respondents near to study area. The corrections were made in the final interview schedule.

A focus group discussion was conducted in order to verify and validate the data collected through household survey. For this a checklist was used to gather the information from FGD. The participants were targeted farmers, local leaders and other concerned stakeholders. It was completely inclusive and participatory. To develop further idea of the study site, informal discussion and interview with key informant was done. Key information interview was done to the progressive farmers, AKC officer, Zone officer and other beneficiaries to obtain key information. For this a separate checklist was used.

Both the primary and secondary data were used. Primary data were obtained through household survey, focus group discussion and key informant interview. Primary data were collected through face-to-face interview. The information on existing production system and use of resource in the study site was collected from farmers. The secondary information was obtained through reviewing different publication mainly produced Department of Agriculture, Ministry of Agriculture and Livestock Development (MOALD), Central Bureau of Statistics (CBS), Nepal Agricultural Research Council (NARC), Agriculture Knowledge Centre (AKC), Gorkha.

\section{Data analysis techniques}

The information collected from the field was first coded and entered into the computer. Data entry and analysis was done by using computer software packages like the Statistical Package for Social Science (SPSS) and Microsoft Excel. The following analyses was performed. Total variable cost

It is the summation of cost incurred in all the variable items during the production of rice.

\section{Gross return}

It is the total return from the quantity of rice marketed. Gross return $=($ price of rice $*$ total quantity of rice $)+$ (price of by-product * total quantity of by-product) (Dhakal, et al., 2019)

\section{Gross margin}

Gross margin is the value of output by producer, which is evaluated at the farm gate price minus the total variable cost.

Gross margin $=$ Gross return - total variable cost (Dhakal, et al., 2019)

\section{Benefit cost analysis}

Cost benefit analysis was done after calculating the total cost and gross return from the rice cultivation. Cost of production was calculated by summing the variable as well as fixed cost items in the production process. For calculating gross return, income from product sale was accounted. So, the benefit cost analysis will be carried out by using formula:

$$
B / C \text { ratio }=\frac{\text { Gross return }}{\text { Total } \cos t}
$$

(Dhakal, et al., 2019)

\section{Problems on production}

The index was prepared mainly considering the qualitative data. Based on responded frequencies, weighted indexes were calculated for the analysis of farmer's perception on the extent of production problems of rice producers. Farmer's perception to the different production problems was ranked by using five points scale of problems compromising most severe, severe, medium severe, less severe and least severe by giving 
weight age on the basis of priority i.e., 1 for first priority, 2 for second, 3 for third, 4 for fourth and 5 for fifth priority. Then the priority index for each variable was calculated by weight age average mean in order to draw valid conclusion and making reasonable decision. The index of importance was computed by using the formula:

Where,

$$
\mathrm{I}_{\mathrm{imp}}=\sum \frac{\text { Sifi }}{N}
$$

$\mathrm{I}_{\mathrm{imp}}=$ index of importance

$\sum=$ summation

$\mathrm{S}_{\mathrm{i}} \quad=\mathrm{I}^{\text {th }}$ scale value

$F_{i}=$ frequency of $i^{\text {th }}$ importance given by the respondents $\mathrm{N}=$ total number of respondents

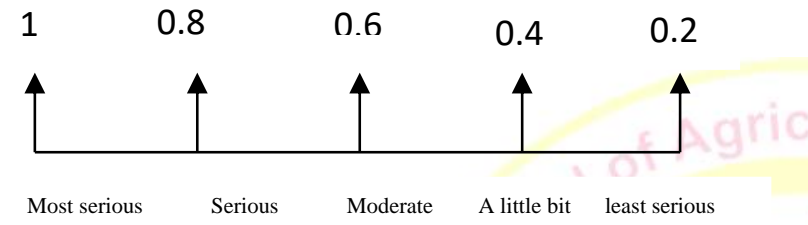

Figure 2. Ranking of scale

\section{RESULTS AND DISCUSSION \\ Demographic and socio-economic information of the respondents}

The assessment of a number of demographic and socioeconomic variables of the respondents such as age, gender, family number and type, dependency ratio, ethnicity, religion and educational status was done. The total respondents $(n=120)$ were categorized into two groups based on mean rice cultivation area ( 0.47 ha). Small holding farmers (area less than $0.47 \mathrm{ha}$ ) was found to be 67 and medium and large holding farmers (area more than $0.47 \mathrm{ha}$ ) was found to be 53 in number.

Distribution of sample household on the basis of age and family members

In the study area, the mean age of household age among the 120 respondents was found to be 49.82 years, the average age of small holding farmers was found to be 49.39 years which is smaller than among the medium and large holding farmers i.e., 50.38 years. Likewise, the average family size among the 120 respondents was found to be 2.92 , economically active population was found to be $65.06 \%$. The average male number was found to be 3.09 and average female was 2.92. The tvalue of female number was found to be statistically significant at $10 \%$ level which means the average female numbers among the small holding farmers was found to be significantly lower than the average female numbers among the medium and large holding farmers. The dependency ratio was found 0.232 .

\section{Socio-demographic characteristics of the} respondents

Within the small farmers, $47.8 \%$ were male while $52.2 \%$ were female. Likewise, within the medium and large farmers, $66 \%$ were male while $34 \%$ were female. Thus, small farmers household were dominated by female while, medium and large farmers household were dominated by male. Overall, the percentage of female household is $44.2 \%$, which was greater than the national census data of female household head i.e., $25.73 \%$ (CBS, 2012). Among the small farmers, $73.1 \%$ farmers had nuclear family type, while $26.9 \%$ farmers had joint family type; whereas, among the medium and large farmers $66 \%$ had nuclear family type, while $34 \%$ farmers had joint family type. And in overall, $70 \%$ were nuclear family and $30 \%$ were joint family.

Different ethnic groups of people were recorded from the research sites. Janajati were dominated over other ethnic groups. In the study area, Janajati were in the highest number $55.8 \%$, followed by Brahmin/Chettri $41.7 \%$ and finally Dalit $2.5 \%$. Education status was categorized into four categories; namely illiterate, primary education, secondary education and higher education and accordingly information was collected from the respondents. Majority of the household head had primary level of education i.e., 62.5\%, followed by secondary level of education $19.2 \%$ and illiterate and higher education had the same percentage i.e., 9.2\%. Overall, the literacy percentage is higher than national census data i.e., $65.9 \%$ (CBS, 2012).

Table 1. Distribution of sample household on the basis of age and family size

\begin{tabular}{|c|c|c|c|c|c|}
\hline Description & $\begin{array}{l}\text { Small } \\
\text { holding } \\
\text { Farmers } \\
(\mathrm{n}=67)\end{array}$ & $\begin{array}{l}\text { Medium } \\
\text { and large } \\
\text { holding } \\
\text { Farmers } \\
(\mathrm{n}=53)\end{array}$ & $\begin{array}{l}\text { Overall } \\
(\mathrm{N}=120)\end{array}$ & $\begin{array}{l}\text { Mean } \\
\text { Difference }\end{array}$ & $\mathrm{t}$-value \\
\hline $\begin{array}{l}\text { Age of } \\
\text { Household } \\
\text { Head } \\
\text { (years) }\end{array}$ & $\begin{array}{l}49.39 \\
(11.27)\end{array}$ & $\begin{array}{l}50.38 \\
(10.45) \\
(0.9\end{array}$ & $\begin{array}{l}49.82 \\
(10.88)\end{array}$ & -0.989 & -0.493 \\
\hline Family size & $\begin{array}{l}5.72 \\
(1.99)\end{array}$ & $\begin{array}{l}6.38 \\
(2.76)\end{array}$ & $\begin{array}{l}6.01 \\
(2.36)\end{array}$ & -0.661 & -1.522 \\
\hline Male & $\begin{array}{l}3.0 \\
(1.22)\end{array}$ & $\begin{array}{l}3.21 \\
(1.63)\end{array}$ & $\begin{array}{l}3.09 \\
(1.41)\end{array}$ & -0.208 & -0.797 \\
\hline Female & $\begin{array}{l}2.71 \\
(1.21)\end{array}$ & $\begin{array}{l}3.19 \\
(1.58)\end{array}$ & $\begin{array}{l}2.92 \\
(1.40)\end{array}$ & -0.477 & $-1.861 *$ \\
\hline $\begin{array}{l}\text { Dependency } \\
\text { ratio }\end{array}$ & $\begin{array}{l}0.324 \\
(0.216)\end{array}$ & $\begin{array}{l}0.331 \\
(0.213)\end{array}$ & $\begin{array}{l}0.323 \\
(0.214)\end{array}$ & -0.066 & -1.58 \\
\hline
\end{tabular}

Note: Figures in the parentheses indicate standard deviation.

Source: Field survey (2020),

* indicates significant at $10 \%$ level of significant

Rice production, inputs used and marketing in the study area

\section{Rice sells}

Rice sells among the small and medium and large farmers were analyzed in the study area. Rice sells was higher among medium and large landholding farmers $(64.2 \%)$ as compared to the small landholding farmers $(32.8 \%)$. On overall, the majority of respondent do not sell rice $53.3 \%$ and $46.7 \%$ sell rice. Majority of farmers sold rice from home $(79.7 \%)$ followed by from field $(18.7 \%)$ and very few farmers sold rice from market $(1.6 \%)$. Rice sells was found to be statistically significant at $1 \%$. 
Table 2. Socio-demographic characteristics of the respondents

\begin{tabular}{|c|c|c|c|c|}
\hline Variables & $\begin{array}{l}\text { Small } \\
\text { holding } \\
\text { farmers } \\
(\mathrm{n}=67)\end{array}$ & $\begin{array}{l}\text { Medium } \\
\text { and } \\
\text { large } \\
\text { holding } \\
\text { farmers } \\
(\mathrm{n}=53)\end{array}$ & $\begin{array}{l}\text { Overall } \\
(\mathrm{N}= \\
120)\end{array}$ & $\begin{array}{l}\text { Chi-squar } \\
\text { test }\end{array}$ \\
\hline \multicolumn{5}{|l|}{$\begin{array}{l}\text { Gender of } \\
\text { household head }\end{array}$} \\
\hline Male & $32(47.8)$ & $35(66)$ & $67(55.8)$ & $4.008 * *$ \\
\hline Female & $35(52.2)$ & $18(34)$ & $53(44.2)$ & \\
\hline \multicolumn{5}{|l|}{ Family type } \\
\hline Nuclear & $49(73.1)$ & $35(66)$ & $84(70)$ & 0.710 \\
\hline $\begin{array}{l}\text { Joint } \\
\text { Ethnicity }\end{array}$ & & \\
\hline Brahimns/Chhetri & $31(46.3)$ & $19(35.8)$ & $50(41.7)$ & 1.738 \\
\hline Janajati & $35(52.2)$ & $32(60.4)$ & $67(55.8)$ & \\
\hline Dalit & $1(1.5)$ & $2(3.8)$ & $3(2.5)$ & \\
\hline \multicolumn{5}{|l|}{$\begin{array}{l}\text { Education of } \\
\text { household head }\end{array}$} \\
\hline Illiterate & $6(9)$ & $5(9.4)$ & $11(9.2)$ & 0.405 \\
\hline \multicolumn{5}{|l|}{ Education } \\
\hline $\begin{array}{l}\text { Secondary } \\
\text { Education }\end{array}$ & 12(17.9) & $11(20.8)$ & $23(19.2)$ & \\
\hline $\begin{array}{l}\text { Higher Education } \\
\text { Source of income }\end{array}$ & $7(10.4)$ & $4(7.5)$ & $11(9.2)$ & \\
\hline Agriculture & $29(43.3)$ & $25(47.2)$ & $54(45)$ & 0.286 \\
\hline Remittance & $15(22.4)$ & $12(22.6)$ & $27(22.5)$ & \\
\hline Service & $15(22.4)$ & $10(18.9)$ & $25(20.8)$ & \\
\hline Business & $8(11.9)$ & $6(11.3)$ & $14(11.7)$ & \\
\hline $\begin{array}{l}\text { Note: Figures in } \mathrm{t} \\
* * \text { indicates signi }\end{array}$ & $\begin{array}{l}\text { arentheses } \\
\text { it at } 5 \% \text { le }\end{array}$ & $\begin{array}{l}\text { indicate st } \\
\text { el of sign }\end{array}$ & $\begin{array}{l}\text { dard devia } \\
\text { ant. }\end{array}$ & \\
\hline Source: Field sur & 2020) & 0 & & \\
\hline
\end{tabular}

Table 3. Rice sells status in the study area

\begin{tabular}{|c|c|c|c|c|c|}
\hline $\begin{array}{l}\text { Rice } \\
\text { sells }\end{array}$ & $\begin{array}{l}\text { Small } \\
\text { Farmers } \\
(n=67)\end{array}$ & $\begin{array}{l}\text { Medium } \\
\text { and large } \\
\text { Farmers } \\
(\mathrm{n}=53)\end{array}$ & $\begin{array}{l}\text { Overall } \\
(\mathrm{N}=120)\end{array}$ & Chi-square & $\begin{array}{l}\mathrm{p}- \\
\text { value }\end{array}$ \\
\hline Yes & $22(32.8)$ & $34(64.2)$ & $56(46.7)$ & $11.659 * * *$ & 0.001 \\
\hline No & $45(67.2)$ & 19(35.8) & $64(53.3)$ & & \\
\hline Tota & $67(100)$ & $53(100)$ & $120(100)$ & & \\
\hline
\end{tabular}

Note: Figures in parentheses indicate the percentage in respective column. *** indicates significant at $1 \%$ level of significant. Source: Field survey (2020)

\section{Source of seed}

Farmers in the study area were asked about the source of their seed. Majority of households used seed saved by them $(55 \%)$ while $37 \%$ purchased seed from agrovets. About $6 \%$ household brought seed from agriculture cooperatives and only $2 \%$ from neighbor. More than $90 \%$ of cereal seeds in Nepal is obtained from traditional or informal system (Paudel, et al., 2013). The majority of respondents $(89.16 \%)$ used traditional canal as the source of irrigation whereas, $7.5 \%$ household used concrete canal and at last $3.33 \%$ household used rainfall as the source of irrigation. The major source of traditional canal irrigation was Daraudi river.

\section{Profitability from rice cultivation}

Respondents were asked whether rice cultivation is profitable or not. Majority of respondents (73.3\%) responded that rice cultivation is profitable while, $26.7 \%$ respondents responded that rice cultivation is not profitable. Profitable was due to the cover of cost of rice cultivation.

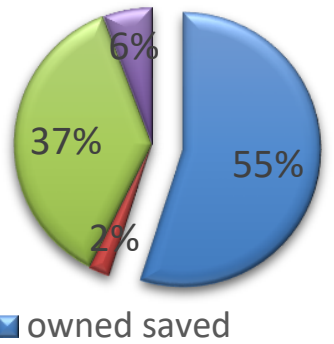

Figure 3. Sources of rice seed

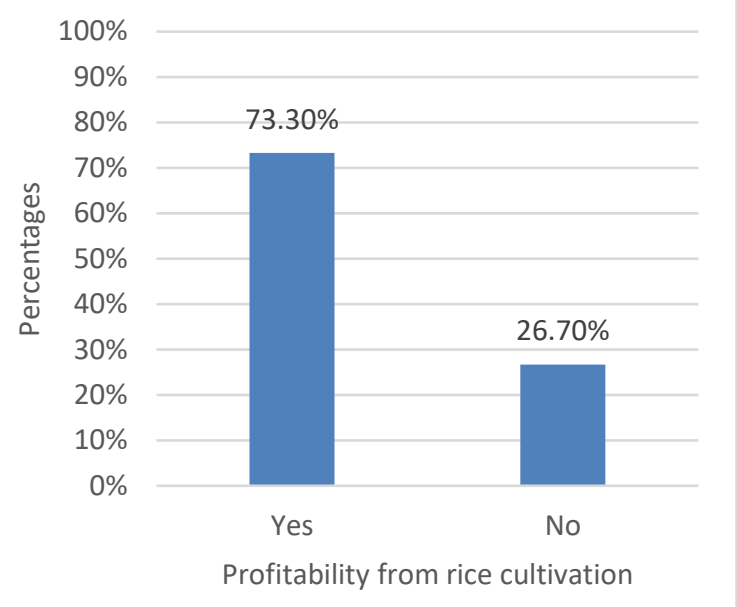

Figure 4. Farmer's opinion about profitability from rice cultivation

Timely availability of seeds and fertilizers

Majority of the respondents i.e., 86 out of 120 (71.7\%) recognized that seed was available on time whereas, 34 respondents $(28.3 \%)$ recognized that seed was not available on time. Unlike seeds, $60.8 \%$ respondents recognized that fertilizers were not available on time and $39.2 \%$ responded that fertilizer was available on time. The potential demand is higher than supply i.e., potential demand and supply in the year 2016/17 was 7,00,000 MT and 3,24,977 MT respectively and low average subsidy on chemical fertilizers i.e. $43.78 \%$, might be the cause of lower available of fertilizers on time.

Financial analysis of rice production

Financial analysis of rice includes the analysis of current scenario of rice production in Gorkha district, total variable cost of production, gross return, gross margin and benefit-cost ratio.

\section{Cost of rice production}

It is the summation of cost incurred in all the variable items during the production of rice. Different costs like labor cost, seed cost, manure cost, fertilizer cost, pesticides cost and machineries cost were summed to calculated the total variable cost of rice production. From the analysis Table 8 , it can be clearly seen that the main portion of the production cost $(75.1 \%)$ was incurred in labor cost. According to the (Sapkota \& Sapkota, 2019) labor cost has the greater contribution to the cost of rice production. Labor cost was found significantly lower in medium and large farmers than in small farmers. 
Similarly, manure cost was found significantly lower in medium and large farmers than in small farmers.

\section{Analysis on the basis of $\mathrm{BC}$ ratio}

If $\mathrm{B}: \mathrm{C}$ ratio $<1$ then, enterprise is in Bankrupt condition.

If $\mathrm{B}$ : $\mathrm{C}$ ratio $=1$ then, enterprise is in Just solvent condition.

If $\mathrm{B}$ : $\mathrm{C}$ ratio > 1 then, enterprise is in Solvent condition. Gross margin is positive and $\mathrm{B}: \mathrm{C}$ ratio is greater than 1 , so this particular enterprise (i.e., Rice Production) can be considered as profitable in the study area.

The overall $\mathrm{BC}$ ratio is 1.28 which means if we invest 1 rupee on rice production, we get return of 1.28 from rice.

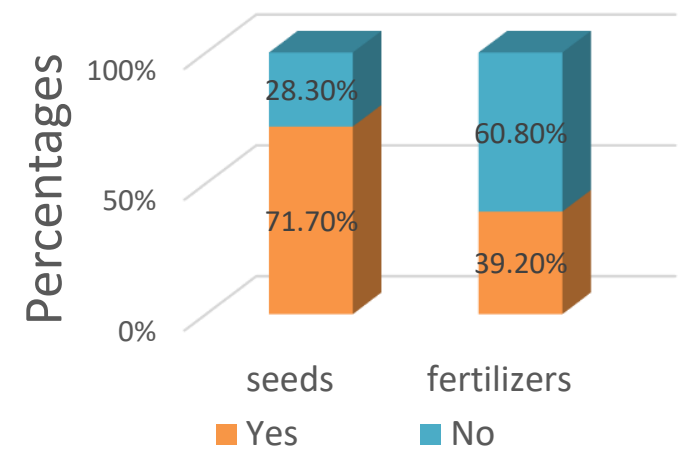

Figure 5. Timely available of seeds and fertilizers

\begin{tabular}{|c|c|c|c|c|c|c|}
\hline \multirow[b]{2}{*}{ Variables } & \multicolumn{4}{|c|}{ Table 4. Cost of rice production per hectare } & \multirow[b]{2}{*}{$\mathrm{t}$-value } & \multirow[b]{2}{*}{ p-value } \\
\hline & $\begin{array}{l}\text { Small Farmers } \\
(\mathrm{n}=67)\end{array}$ & $\begin{array}{l}\text { Medium and large } \\
\text { Farmers }(n=53)\end{array}$ & $\begin{array}{l}\text { Overall } \\
(\mathrm{N}=120)\end{array}$ & $\begin{array}{l}\text { Mean } \\
\text { Difference }\end{array}$ & & \\
\hline Labor cost $\mathrm{t}^{1}$ & $93346(75.3)$ & $85433.2(74.8)$ & $89851.2(75.1)$ & 7912.8 & $2.992 * * *$ & 0.003 \\
\hline Seed cost & $4647.6(3.7)$ & $4531.4(4.0)$ & $4596.2(3.8)$ & 116.2 & 0.356 & 0.722 \\
\hline Manure cost & $9217.8(7.4)$ & $8669.2(7.6)$ & $8975.4(7.5)$ & 548.6 & $2.491 * *$ & 0.014 \\
\hline Fertilizer cost ${ }^{2}$ & $4423.6(3.6)$ & $4359.6(3.8)$ & $4395.4(3.7)$ & 64 & 0.156 & 0.876 \\
\hline Pesticide cost & $1856.8(1.5)$ & $1729.6(1.5)$ & $1800.6(1.5)$ & 127.2 & $1.820^{*}$ & 0.071 \\
\hline Machineries and bullock & $10496.6(8.5)$ & $9519.4(8.3)$ & $10065(8.4)$ & 977.2 & 1.499 & 0.136 \\
\hline Total & $123988.4(100)$ & $114242.4(100)$ & $119683.8(100)$ & & & \\
\hline
\end{tabular}

Note: Figures in parentheses indicate the percentage to their respective columns. $*, * *$ and $* * *$ indicate significant at $10 \%, 5 \% \& 1 \%$ level of significance respectively. Source: Field survey (2020)

Table 5. Return from rice production per hectare

$\begin{array}{lllllll}\text { Variables } & \begin{array}{l}\text { Small } \\ \text { Farmers }(\mathrm{n}=67)\end{array} & \begin{array}{l}\text { Medium and } \\ \text { large }\end{array} & \begin{array}{l}\text { Overall }(\mathrm{N}=120) \\ \text { Farmers(n=53) }\end{array} & \begin{array}{l}\text { Mean } \\ \text { Difference }\end{array} & \text { t-value } & \text { p-value } \\ & & & & \\ \text { Rice grain } & 119906.8(79.6) & 122549(79.5) & 121073.8(79.5) & -2642.2 & -0.842 & 0.402 \\ \text { Straw } & 30794.4(20.4) & 31573(20.5) & 31138.2(20.5) & -778.6 & -1.593 & 0.114 \\ \text { Total } & 150701.2(100) & 154122(100) & 152212(100) & & & \end{array}$

Note: Figures in parentheses indicate the percentage to their respective columns.

Source: Field survey (2020)

Table 6. BC ratio of rice cultivation in study area

$\begin{array}{llll}\text { B: C Ratio } & \text { Small Farmers }(\mathrm{n}=67) & \begin{array}{l}\text { Medium and large } \\ \text { Farmers }(\mathrm{n}=53)\end{array} & \text { Overall }(\mathrm{N}=120) \\ & 1.22 & 1.35 & 1.27\end{array}$

Source: Field survey (2020)

\section{Problems in rice production}

Different problems regarding the rice production were identified in study area. Those problems were ranked using scaling technique. Five different problems were asked among the respondents and they were ranked on the basis of their weightage.

The study revealed that the major problems in rice production in study area was insect pests and disease problems, followed by lack of quality seeds, lack of fertilizers and pesticides, lack of irrigation and lack of extension services. According to the (Upadhyaya, 1996), technical constraints like Insects, disease and weeds were the major production problems in rice. Due to the insect pests and disease in study area the production of rice was low than its actual potential.

Table 7. Ranking of rice production problems Production problems Index Insect pests and diseases problem $\quad 0.867$ Lack of quality seeds $\quad 0.717$ Lack of fertilizers and pesticides $\quad 0.633$ III Lack of irrigation $\quad 0.558$ Lack of extension services $0.433 \mathrm{~V}$

${ }^{1}$ Labor cost $=$ Nursery preparation, land preparation, planting, weeding, harvesting, threshing

${ }^{2}$ Fertilizer cost $=$ Urea, DAP, MOP, Zinc sulphate 


\section{CONCLUSION}

From above results and discussions, we can conclude that the rice farming is profitable farming in the study area. Despite the cost of production of rice is high especially the labor cost, the farming is in solvent condition. If we are able to decrease the cost of production by optimum utilization of the resources, the profit can be increased. Timely control of insect pests and diseases led to increase in the production of rice. Also, effective and optimum use of agricultural inputs like seeds, fertilizers, pesticides, manures help not only in reduction of cost but also increase in gross margin.

Farm mechanization helps to decrease the labor cost of production which contributes the major portion of cost. There should be the provision of timely availability of seeds and especially fertilizers and scientific rice cultivation training program to the farmers, which can ensure the potential production of rice.

\section{REFERENCES}

CBS. 2012. Nepal Population and Housing Census 2011. Kathmandu, Nepal: Central Bureau of Statistics. Depatment of Customs. (2017/18). Annual Foreign Trade Statistics. Kathmandu: Ministry of Finance.

Dhakal, R., Bhandari, S., Joshi, B., Aryal, A., Kattel, R., and Dhakal, S. 2019. Cost-benefit analysis and resource use efficiencyof rice production system in different agriculture landscapes in Chitwan district, Nepal. Archives of agricultural and environmental science, 442-448.

Fageria, N. 2007. Yield Physiology of Rice. Journal of Plant Nutrition, 843-879.

Fairhurst, T., \& Dobermann, A. 2002. Rice in Global Food Supply. Better Crops Intrenational.

Greenland, D. 1997. The sustainability of rice farming. Wallingford, UK: CAB International.

Gumma, M. K., Gauchan, D., Nelson, A., Pandey, S., and Rala, A. 2011. Temporal changes in ricegrowing area and their impact on livelihood over a decade: A case study of Nepal. Agriculture, Ecosystems and Environment, 382-392.

Joshi, N. P., Maharjan, K. L., and Piya, L. 2011. Production Economics of Rice in Different Development Region of Nepal. Journal of International Development and Cooperation, 103-112.
Kafle, L. 2019. Rice Import Increases by 21 per cent. Kathmandu: The Rising Nepal.

Komleh, S. P., Sefeedpari, P., and Rafiee, S. 2011. Energy and economic analysis of rice production under different farm level in Guilan province of Iran. Elsevier, 5824-5831.

Mallick, R. 1981. Rice in Nepal. Kathmandu, Nepal: KalaPrakashan.

MoAD. 2015. Rice Varietal Mapping in Nepal: Implication for Development and Adoption. Kathmandu: Government of Nepal.

MOALD. 2017. Nepal Agriculture Statisctics 2074/75. Ministry of Agriculture and Livestock Development.

MoALD. 2018. Nepal Agriculture Statistics 2074/75. GON.

Pandey, S., Gauchan, D., Malabayabas, M., \& Hardy, B. 2012. Patterns of adoption of improved rice varieties and farm-level impact stress prone in rain-fed areas of South Asia. International Rice Research Institute.

Paudel, M., Pokhrel, S., Gadal, N., Ferrara, G.-O., KC, D., Joshi, P., and Humagain, R. 2013. An overview of different seed production initiatives in Nepal. Agronomy Journal of Nepal, 1-10.

PMAMP. 2016. Project Document of Prime Minister Agriculture Modernization Project (PMAMP). Singhadurbar, Kathmandu: GON, Ministry of Agriculture Development.

Sapkota, S., \& Sapkota, S. 2019. Benefit Cost Analysis of Different Rice Varieties in Kapilvastu District, Nepal. International Journal of Applied Sciences and Biotechnology, 222-226.

Tripathi, B. P., Bhandari, H. N., \& Ladha, J. 2018. Rice Strategy for Nepal. ACTA scientific Agriculture, 171-180.

Upadhyaya, H. 1996. Rice research in Nepal: Current status and future priorities. In IRRI, Rice research in Asia: Progress and Priorities (pp. 193-215). Walling Ford: CAB International.

Citation: Paudel, S.; Parajuli, S.; Mahatara, B.; Budhathoki, S. and Kattel, R.R. 2021. Economics of rice production under rice zone in Gorkha District, Nepal. International Journal of Agricultural and Applied Sciences, 2(1): 145-150. https://doi.org/10.52804/ijaas2021.2119

Copyright: (C) Paudel et.al 2021. Creative Commons Attribution 4.0 International License. IJAAS allows unrestricted use, reproduction, and distribution of this article in any medium by providing adequate credit to the author (s) and the source of publication. 